\title{
Intangible assets disclosed by public universities in Czech Republic
}

\author{
Olga Hasprová \\ Faculty of Economics, Technical University of Liberec, \\ Liberec, Czech Republic \\ olga.hasprova@tul.cr. \\ Zdeněk Brabec \\ Faculty of Economics, Technical University of Liberec, \\ Liberec, Czech Republic \\ zdenek.brabec@tul.cr.

\section{Jiř́ Rozkovec} \\ Faculty of Economics, Technical University of Liberec, \\ Liberec, Czech Republic \\ jiri.rozkovec@tul.cr.
}

Abstract. The process of scientific outcomes' evaluation used for the purposes of financing research institutions in Czech Republic is quite complicated and often unpredictable. The conditions under which scientific outcomes are evaluated often change ex post, thus causing significant problems to researchers. Therefore, the aim of this article is to propose a new methodology for evaluation of scientific outcomes in Czech Republic. The research compares two different methods of scientific outcomes' assessment applied by Czech public universities - the methodology of the Section for Science, Research and Innovation (SSRI) of the Government of Czech Republic and the requirements of Czech accounting legislation. More specifically, the number of scientific outcomes evaluated according to the SSRI is compared with the amount of intangible assets disclosed in their financial statements for the years 2008-2015. For this purpose, the multiple regression analysis is used. The results of this research confirm that the methodology used by the SSRI may, under certain conditions, be replaced by the amount of intangible assets disclosed according to the requirements of Czech accounting legislation. Generally speaking, despite having some weaknesses, accounting requirements seem to provide more stable results when evaluating scientific outcomes than the methodology used by the SSRI.

Keywords: financial statements, intangible assets, intellectual property, public university, research and development.

JEL Classification: I23, M41 


\section{INTRODUCTION}

Currently, information on important discoveries in the field of research and development, and its impact on the manufacturing sector and people's lives, is more often published in both scientific and popular articles. The rising importance of intangible assets, both in manufacturing and consumption, seems to be enabled by the participation of research institutions including, among others, public universities.

Increased competition in the manufacturing sector leads to pressure on activities and the evaluation of public universities, especially technical ones. Similar trends could also be observed in other countries, e.g. Israel (Cohen \& Davidovitch, 2015). Assessment of the activities performed by public universities can be achieved using various perspectives. At present, the outcomes of Czech public universities in the field of science and research are assessed using the methodology of the Section for Science, Research and Innovation of the Government of Czech Republic (SSRI). The evaluation process is quite complicated and often unpredictable. The conditions under which scientific outcomes are evaluated often change ex post, thus causing problems to researchers (Pelegrýn, 2011). Moreover, application of this methodology is limited to the territory of Czech Republic only.

To avoid the abovementioned problems connected with the use of the SSRI methodology for evaluation of scientific outcomes, under a certain level of simplification, the amount of intangible assets disclosed in financial statements of public universities prepared according to Czech accounting legislation can be used as another method of evaluating the scientific outcomes of Czech public universities.

In practice, there are some problems concerning the recognition and measurement of intangible assets, for example, exact specification of intangible assets, their classification or determination of the moment at which they are recognised. In addition, Ramírez, Tejada and Gordillo (2013) mention cooperation as one of the main aspects of intangible assets, which is unfortunately not recognised by the current accounting legislation as such. Furthermore, measurement of intangible assets is often complicated, as well as the determination of their useful life. Decision on the recognition of intangible assets is often dependent on the probability of realizing the expected future benefits from investing in intangible assets. If the expected future benefits are more likely to be greater than $50 \%$, then intangible assets can be recognised (Hunter, Webster, \& Wyatt, 2012).

To avoid some of the abovementioned problems in the recognition and measurement of intangible assets, Krstić and Dordević (2010) suggest that companies should prepare a report on intangible assets or intellectual capital on a voluntary basis. This should reduce the gap between market and book value of companies.

The aim of this article is to propose a new methodology for evaluation of scientific outcomes in Czech Republic. Firstly, the article analyses the current approach to monitoring scientific outcomes in this country. After that, intangible assets are analysed from different perspectives. Subsequently, the problems connected with recognition and measurement of intangible assets are discussed. To do so, the requirements of Czech accounting legislation and the International Financial Reporting Standards (IFRS) are compared. Afterwards, the amount of scientific outcomes measured by the SSRI methodology and the amount of intangible assets disclosed by Czech public universities are used to develop and present a model for evaluating scientific outcomes in Czech Republic. 


\section{CURRENT SITUATION IN EVALUATING THE SCIENTIFIC OUTCOMES IN THE CZECH REPUBLIC}

In addition to the Czech accounting legislation that regulates the accounting information embodied in the financial statements, the outcomes of research institutions including public universities are evaluated according to the methodology of the Section for Science, Research and Innovation of the Government of the Czech Republic (SSRI) valid for the years 2013 - 2016. This evaluation is one of the tools used for the distribution of financial resources provided by the Government of the Czech Republic to public universities.

Evaluation of research and developments outcomes according to this methodology includes only such scientific outcomes that are applied through the Research and development and innovation information system of the Czech Republic. The outcomes for the previous five years are attributed to individual research and development institutions using the moving average.

Using this method, the outcomes of research institutions are structured into three mutually interconnected pillars:

- $\mathbf{1}^{\text {st }}$ pillar contains disciplinary related evaluation of publication outcomes. Depending on the discipline some outcomes are not evaluated at all and some achieve only a proportion of possible points according to the total number of points available for individual disciplines.

- $2^{\text {nd }}$ pillar is focused on evaluating the quality of institutions. A limited number of selected outcomes attributed to these institutions (best $20 \%$ ) are included into the total evaluation.

- $\quad 3^{\text {rd }}$ pillar evaluates patents and non-publication outcomes of applied research. Each patent is granted with the same number of points and the number of points attributed to other outcomes is dependent on the amount of financial support granted to the projects of applied or contractual research.

This methodology was firstly applied for the evaluation of the outcomes of the year 2012 and its implementation was gradual. In the year 2013, the first and third pillars were introduced, while the second pillar came into power in the year 2014. Another change in the methodology is applied to the outcomes of the year 2017 and onwards.

\section{INTANGIBLE ASSETS AS A BASIS FOR EVALUATING THE SCIENTIFIC OUTCOMES IN THE CZECH REPUBLIC}

\subsection{Defining intangible assets}

In the scientific literature, many various definitions of intangible assets can be found. However, there is no specific definition of intangible assets reflecting the special needs of universities and research institutes.

According to Lev (2001) intangible assets can be defined, however, their precise recognition and measurement is difficult. Respecting the legal requirements intangible assets existing in companies and other institutions can be defined from different perspectives. Each of them is applicable in different situations depending on the purposes of defining, recognising and measuring intangible assets. Therefore, the following perspectives can be distinguished:

- legal protection perspective - intangible assets are specified in detail in various legal acts, mainly as intellectual property,

- management perspective - in different organizations different things are considered to be intangible assets, 
- accounting perspective - deals with the definition, recognition and measurement of intangible assets according to various accounting systems and in different accounting entities.

The definition of intangible assets seen from the perspective of intellectual property protection is analysed by many authors. Dobiáš (2008) considers intellectual property as an intangible asset resulting from a mental activity that is independent on a tangible substance. The subject of disposal (sale, donation, investment heritage or other transfer) is not the intangible asset itself but only the rights connected to it. Therefore, these rights are called intellectual property rights. Čada (2009) describes the term of intellectual property in a narrower sense compared to intangible assets. Intellectual property is characterized by the ability of becoming the object of social relations, especially trade relations. According to CandelinPalmqvist, Sandberg and Mylly (2012) intellectual property rights seem to have rising importance, especially for innovative firms seeking international growth. On the other hand, Papageorgiadis and Sharma (2016) have found a nonlinear relationship between intellectual property rights and innovation.

Intellectual property, therefore, reflects the legal existence and economic value that are important attributes of intangible assets. Despite the different definitions of the term intellectual property, it is clear that intellectual property rights can provide companies and other entities with new earnings and, therefore, they are a tool for increasing their competitiveness. (Blomquvist, 2004)

To achieve the anticipated future earnings companies have to protect their intellectual property rights. To do so, companies have to consider different approaches to the protection of intellectual property rights applied in various countries. (Holyoak \& Torremans, 2013) According to Mingaleva and Mirskikh (2013) the main shortcomings of the legal regulation for intellectual property are unsatisfactory protection of certain types of intellectual property, the dual interpretation of legal standards and the weak regulation of technical documentation on intellectual property. Hertzfeld, Link and Vonortas (2006) highligt the specific problems in the protection of intellectual property rights in research partnerships between companies, universities and state institutions. Similar issues are strengthened by Ayerbe et.al. (2014) analysing the defence industry in France.

\subsection{Intangible assets in financial accounting}

Public universities have to prepare their financial statements in accordance with Regulation No. 504/2002 implementing the Accounting Act No. 563/1991 as subsequently amended.

The Czech accounting legislation does not provide any general definition of intangible assets but it explicitly lists the items that should be included in a specific item of the financial statements. There is no economic justification of their content, so the legislation is not able to provide a relevant guideline that should help prepare financial statements. An item is recognized as a fixed intangible asset if its useful life exceeds one year and the acquisition cost exceeds the value limit specified by the company. Useful life is described as a period during which the asset can be used itself or may serve as a basis for the component of other procedures and solutions. (Malíková \& Černíková, 2013)

The following text describes selected groups of intangible assets according to the Czech accounting legislation (prevailing on January 1,2016). With regard to the above mentioned classification of intellectual property, intangible assets can be classified as follows:

- Intangible results of research and software contain such outcomes and software that are not included in industrial or other valuable rights. These intangible assets were either internally generated and are held for trading or they were purchased from other entities.

- Valuable rights include industrial and similar intangible rights. Most of them are the outcomes of intellectual creative activities that are in the form of patents, copyrights, industrial or utility rights. 
Also, these intangible assets were either internally generated and held for trading or purchased from other entities.

- Low value intangible assets contain especially intangible results of research, software, valuable rights and other intangible assets with a useful life longer than one year and acquisition cost of individual items between $7000 \mathrm{CZK}$ and $60000 \mathrm{CZK}$ that was purchased no later than December 31, 2002.

- Other intangible assets contain such intangible assets that are not included in other groups, in particular preference limits for the production of certain specific agricultural products and allowances for emissions of greenhouse gases regardless of their cost.

- Intangible assets in progress include the acquisition of intangible assets until they are recognised.

- Advances paid on intangible assets contain long- and short-term advances paid on the purchase of intangible assets.

On the other hand, as intangible assets cannot be recognised, for example, start-up costs, expert opinions, market researches, development plans, various certification processes, proposals for promotional and advertising campaigns.

A bit controversial is also the recognition of intangible assets in progress. This issue is related to the value attributable to the costs spent on the development of these assets. The problem is that a company does not know whether the assets will be marketable in the future. So there is no proof that they will provide sufficient profits to cover the cost invested in their creation. Considering the principle of accrual accounting, it would be more appropriate to recognize these assets as expenses of the current accounting period. These assets may be potentially recognised once they have been completed and only if they meet the required conditions for their recognition. (Sedláček, 2010)

Intangible assets disclosed in the financial statements of public universities are mostly the outcomes of intellectual creative activities, including research and development projects. Such outcomes can be recognised as tangible or intangible assets (in the form of patents, utility designs etc.). These scientific projects usually last for a longer period, often several years. Related expenses are expected to be covered by selling the outcomes of these projects in the future. Accounting enables the evidence of these expenses in the form of complex pre-paid expenses. After achieving the set target, these expenses are recognised as expenses of the current period (for a maximum period of 4 years).

To reflect the decrease in the value of long-lived the straight-line method is usually used. This method is dependent on the length of the useful life of an asset. Therefore, the determination of the useful life of individual assets is important (Malíková \& Brabec, 2012).

In addition to the above mentioned issues, the Czech accounting legislation is strongly influenced by the tax law because the gross profit determined according to the accounting rules is subsequently used as a basis for the calculation of corporate income tax. Therefore, for example, by calculating the depreciation and amortisation, tax requirements are often preferred to accounting requirements. This approach does not provide a true and fair view as required, for example, by the IFRS and, therefore, the reported values of fixed assets, operating expenses and profit/loss are distorted. Such accounting records may only be used as a tool for determining tax liability, but not for decision-making in a company (Horák \& Malíková, 2011).

With regard to the changes in Czech accounting legislation in recent years, it can be assumed that the influence of IFRS on Czech accounting legislation will be rising. Therefore, the practices embodied in IFRS can also be introduced into the legislation used for the preparation of the financial statements of Czech public universities. This approach should increase the comparability of the financial statements in the international context. 
IFRS recognises an item as an asset if it satisfies the definition of an asset that is embodied in the conceptual framework. So this item must be controlled by the company, it is a result of past events and its economic benefits will flow to the company. Furthermore, the economic benefits (sale or use of intangible assets) associated with this item must be probable and the cost or value of the item must be measured reliably. IAS 38 requires another critical attribute for recognition of an intangible asset that is called identifiability. It means that the intangible asset must be separable, so it is capable to be sold, transferred, licensed, rented, or exchanged to be separable and furthermore, this intangible asset arises from contractual or other legal rights (IASB, 2014).

The IFRS requirements on disclosure of intangible assets differ from those of Czech accounting legislation in many ways. The main difference is the response to the progressive development in the field of intangible assets, especially in the most extensive classification of intangible assets. However, it is obvious that IFRS only defines certain characteristics that are essential for the recognition of intangible assets. But, in fact of all the assets listed as intangible ones according to Czech accounting legislation can also be recognised according to IFRS (Svačina, 2010).

Amortisation of intangible assets is calculated using the straight-line method which is dependent on the useful life of individual assets. Only those intangible assets with a definite useful life can be amortised. Otherwise, the period for which the asset generates future benefits cannot be determined. Useful life shall not be too short even if the technological progress on some intangible assets is very rapid. On the other hand, useful life shall not be in any case longer than the existence of contractual or other legal rights associated with the use of certain intangible assets.

\section{RESEARCH METHODOLOGY AND DATA}

\subsection{Research purpose and objectives}

The role of intangible assets at Czech public universities is analysed from two different perspectives. Firstly, research and developments outcomes of public universities are evaluated according to the methodology of the Section for Science, Research and Innovation of the Government of the Czech Republic (SSRI). On the other hand, the amount of intangible assets disclosed by Czech public universities is assessed using the comparative analysis of the information embodied in the financial statements of Czech public universities. To analyse the relationship between the SSRI and the intangible assets disclosed by Czech public universities, the multiple regression analysis (linear model and the stepwise backwards regression) is used.

As the research sample, all 26 public universities in the Czech Republic are chosen. As the data for the year 2016 evaluating the scientific outcomes of public universities according to the SSRI methodology are still not available, the multiple regression analysis covers only the period from 2008 to 2015.

\subsection{Research findings at Czech public universities}

\subsubsection{Assessing the science and scientific outcomes at Czech public universities}

Firstly, research and developments outcomes of public universities are evaluated according to the methodology of the SSRI. The input data for this analysis were obtained through the Research and development and innovation information system of the Czech Republic. The amount of scientific outcomes achieved by individual public universities in the Czech Republic is shown in Table 1. 
The number of points achieved by Czech public universities in years 2008 - 2015

\begin{tabular}{|c|c|c|c|c|c|c|c|c|}
\hline \multirow{2}{*}{ University } & \multicolumn{8}{|c|}{ Year } \\
\hline & 2008 & 2009 & 2010 & 2011 & 2012 & 2013 & 2014 & 2015 \\
\hline $\begin{array}{l}\text { Academy of Performing Arts in } \\
\text { Prague }\end{array}$ & 2,190 & 3,466 & 4,615 & 5,151 & 5,818 & 6,139 & 6,107 & 5,892 \\
\hline Academy of Fine Arts in Prague & 236 & 201 & 270 & 537 & 835 & 1,030 & 1,102 & 1,473 \\
\hline $\begin{array}{l}\text { Czech University of Life Sciences } \\
\text { Prague }\end{array}$ & 11,560 & 19,072 & 30,097 & 39,261 & 53,785 & 65,496 & 74,067 & 80,078 \\
\hline Czech Technical University in Prague & 87,631 & 155,587 & 194,547 & 211,796 & 235,606 & 271,116 & 268,036 & 251,010 \\
\hline $\begin{array}{l}\text { Janáček Academy of Music and } \\
\text { Performing Arts in Brno }\end{array}$ & 1,916 & 980 & 1,518 & 1,632 & 2,242 & 2,368 & 2,062 & 1,862 \\
\hline $\begin{array}{l}\text { University of South Bohemia in } \\
\text { České Budějovice }\end{array}$ & 21,440 & 39,082 & 55,586 & 65,244 & 75,283 & 85,145 & 85,444 & 78,572 \\
\hline Masaryk University & 78,608 & 122,392 & 191,667 & 197,256 & 209,252 & 240,618 & 245,669 & 241,585 \\
\hline Mendel University in Brno & 17,024 & 23,058 & 30,722 & 37,076 & 44,528 & 56,206 & 60,271 & 61,498 \\
\hline University of Ostrava & 5,135 & 10,318 & 18,683 & 23,417 & 28,607 & 36,757 & 37,758 & 37,845 \\
\hline Silesian University in Opava & 4,065 & 7,062 & 11,649 & 12,796 & 14,907 & 19,536 & 21,882 & 22,500 \\
\hline Technical University of Liberec & 10,200 & 14,149 & 21,218 & 25,653 & 31,379 & 39,963 & 43,091 & 42,968 \\
\hline University of Hradec Králové & 1,567 & 3,623 & 7,739 & 10,506 & 14,349 & 19,430 & 20,312 & 21,449 \\
\hline $\begin{array}{l}\text { University of J. E. Purkyně in Ústí } \\
\text { nad Labem }\end{array}$ & 5,113 & 7,753 & 10,794 & 13,999 & 17,112 & 20,935 & 21,845 & 21,251 \\
\hline Charles University in Prague & 246,366 & 429,291 & 487,227 & 513,338 & 544,458 & 606,172 & 596,258 & 562,112 \\
\hline Palacký University Olomouc & 40,332 & 72,485 & 101,708 & 122,835 & 153,671 & 182,071 & 188,254 & 191,917 \\
\hline University of Pardubice & 21,670 & 39,522 & 49,098 & 56,925 & 63,489 & 70,160 & 70,472 & 67,044 \\
\hline Tomas Bata University in Zlín & 6,169 & 9,701 & 17,823 & 22,529 & 32,732 & 43,136 & 46,859 & 45,006 \\
\hline $\begin{array}{l}\text { University of Veterinary and } \\
\text { Pharmaceutical Sciences Brno }\end{array}$ & 8,080 & 13,423 & 16,599 & 18,838 & 19,244 & 22,246 & 22,464 & 22,082 \\
\hline $\begin{array}{l}\text { VŠB - Technical University of } \\
\text { Ostrava }\end{array}$ & 12,912 & 20,670 & 35,287 & 52,308 & 72,274 & 93,000 & 100,379 & 100,091 \\
\hline University of Economics, Prague & 12,126 & 14,750 & 25,529 & 24,030 & 23,553 & 28,639 & 28,083 & 26,522 \\
\hline $\begin{array}{l}\text { University of Chemistry and } \\
\text { Technology, Prague }\end{array}$ & 41,733 & 62,164 & 65,174 & 79,556 & 86,497 & 100,248 & 101,874 & 101,603 \\
\hline College of Polytechnics Jihlava & 0 & 0 & 0 & 0 & 0 & 258 & 359 & 640 \\
\hline $\begin{array}{l}\text { Institute of Technology and Business } \\
\text { in České Budějovice }\end{array}$ & 7 & 133 & 0 & 0 & 1,122 & 1,260 & 1,247 & 1,238 \\
\hline $\begin{array}{l}\text { Academy of Arts, Architecture and } \\
\text { Design in Prague }\end{array}$ & 0 & 600 & 1,166 & 1,106 & 1,306 & 1,519 & 1,988 & 2,090 \\
\hline Brno University of Technology & 62,100 & 88,667 & 115,882 & 134,934 & 148,357 & 175,870 & 170,845 & 157,437 \\
\hline University of West Bohemia & 20,956 & 29,495 & 49,036 & 62,430 & 71,835 & 87,381 & 90,907 & 90,034 \\
\hline Total & 719,136 & $1,187,644$ & $1,543,634$ & $1,733,153$ & $1,952,241$ & $2,276,699$ & $2,307,635$ & $2,235,799$ \\
\hline
\end{tabular}

Source: Compiled by the authors based on the data gathered from (Research, Development and Innovation Council, 2016).

Table 1 shows that the total amount of points according to the SSRI methodology is rising quite rapidly. Using this methodology, the scientific outcomes seem to be considerably dependent on the size of the universities. The leader is the biggest university in the Czech Republic, the Charles University in Prague, which has more than twice as many points as the two following universities, namely the Czech Technical University in Prague and Masaryk University. The rising numbers have been caused by both increasing performance of the universities and changes in the methodology in evaluating the scientific outcomes. 


\subsubsection{The amount of intangible assets disclosed by Czech public universities}

The second perspective used to analyse scientific outcomes of Czech public universities is focused on accounting information. As the input data, the annual economic reports of the 26 public universities in the Czech Republic are used. The research period covers the years 2008-2016. Table 2 shows absolute amounts of intangible assets disclosed by the analysed universities in the year 2016, regardless of their scientific orientation or the number of their researchers. The item other intangible assets includes low value intangible assets, other intangible assets, intangible assets in progress and advances paid on intangible assets as they are disclosed in the financial statements in accordance with the requirements of Czech accounting legislation.

According to the total amount of intangible assets, the most important item is software, which makes about $85 \%$ of the amount of total intangible assets. The selected universities use software both in their research and for educational activities. Intangible results of research and development are disclosed only by 6 universities, which is about a quarter of the total number of Czech public universities. The largest relative proportion of intangible results of research and development to total intangible assets is disclosed by Brno University of Technology (about $13.4 \%$ ) and the Technical University of Ostrava (about $4.8 \%$ ). In the case of valuable rights the situation concerning their disclosure is a bit better. Valuable rights are disclosed by 12 universities. The largest absolute amount of valuable rights was disclosed by the Technical University of Ostrava and the University of Pardubice. As the relative proportion of valuable rights to total intangible assets is taken into account, the leaders are the University of Veterinary and Pharmaceutical Sciences Brno with 50.6 \% and the University of Pardubice with $34.1 \%$.

Average amortisation of intangible assets is about $83.7 \%$ and it is mostly influenced by amortisation of software. But the level of amortisation is different at analysed universities. The most amortised intangible assets are disclosed by the University of Economics, Prague (about $94.8 \%$ ), whereas the opposite situation is at the Institute of Technology and Business in České Budějovice with the amortisation rate of about $58.4 \%$. Other types of intangible assets (except from intangible assets in progress and advances paid on intangible assets) are usually completely amortised. 
Intangible assets disclosed by Czech public universities in the year 2016

\begin{tabular}{|c|c|c|c|c|c|c|}
\hline \multirow[b]{2}{*}{ University } & \multicolumn{5}{|c|}{ Intangible assets in purchase price (in thousands of CZK) } & \multirow[b]{2}{*}{$\begin{array}{c}\text { Amortisation of } \\
\text { intangible assets } \\
\text { (in \%) }\end{array}$} \\
\hline & $\begin{array}{l}\text { Intangible results } \\
\text { of research and } \\
\text { development }\end{array}$ & Software & Valuable rights & $\begin{array}{l}\text { Other intangible } \\
\text { assets }\end{array}$ & $\begin{array}{c}\text { Total } \\
\text { intangible } \\
\text { assets }\end{array}$ & \\
\hline Academy of Performing Arts in Prague & 0 & 18,614 & 1,223 & 1,123 & 20,960 & 77.37 \\
\hline Academy of Fine Arts in Prague & 0 & 7,499 & 0 & 54 & 7,553 & 78.41 \\
\hline Prague & 0 & 83,472 & 0 & 3,458 & 86,955 & 69.53 \\
\hline Czech Technical University in Prague & 0 & 248,158 & 0 & 10,701 & 258,859 & 87.11 \\
\hline Performing Arts in Brno & 0 & 16,719 & 0 & 529 & 17,248 & 85.45 \\
\hline Budějovice & 0 & 57,211 & 204 & 7,852 & 65,428 & 89.30 \\
\hline Masaryk University & 1,959 & 291,336 & 11,111 & 23,538 & 327,944 & 90.61 \\
\hline Mendel University in Brno & 5,418 & 105,759 & 250 & 6,370 & 117,797 & 91.80 \\
\hline University of Ostrava & 0 & 36,739 & 0 & 3,406 & 40,220 & 93.61 \\
\hline Silesian University in Opava & 0 & 35,810 & 223 & 2,329 & 38,362 & 90.13 \\
\hline Technical University of Liberec & 252 & 48,188 & 0 & 2,133 & 50,572 & 91.10 \\
\hline University of Hradec Králové & 0 & 37,483 & 0 & 1,605 & 39,088 & 88.90 \\
\hline $\begin{array}{l}\text { University of J. E. Purkyně in Ústí nad } \\
\text { Labem }\end{array}$ & 0 & 75,224 & 786 & 2,245 & 78,255 & $\overline{94.06}$ \\
\hline Charles University in Prague & 0 & 300,245 & 0 & 11,440 & 312,786 & 78.73 \\
\hline Palacký University Olomouc & 0 & 205,738 & 11,552 & 19,374 & 236,664 & 81.00 \\
\hline University of Pardubice & 0 & 76,715 & 42,208 & 4,658 & 123,581 & 82.61 \\
\hline Tomas Bata University in Zlín & 0 & 113,830 & 6,891 & 4,205 & 124,926 & 86.58 \\
\hline $\begin{array}{l}\text { University of Veterinary and } \\
\text { Pharmaceutical Sciences Brno }\end{array}$ & 0 & 17,740 & 18,254 & 54 & 36,048 & 81.00 \\
\hline VŠB - Technical University of Ostrava & 17,387 & 178,544 & 44,150 & 120,694 & 360,775 & 59.12 \\
\hline University of Economics, Prague & 0 & 38,580 & 0 & 0 & 38,580 & 94.76 \\
\hline $\begin{array}{l}\text { University of Chemistry and Technology, } \\
\text { Prague }\end{array}$ & 0 & 44,909 & 0 & 3,973 & 48,881 & 93.37 \\
\hline College of Polytechnics Jihlava & 0 & 14,466 & 0 & 92 & 14,558 & 92.02 \\
\hline $\begin{array}{l}\text { Institute of Technology and Business in } \\
\text { České Budějovice }\end{array}$ & 0 & 10,606 & 0 & 0 & 10,606 & 58.38 \\
\hline $\begin{array}{l}\text { Academy of Arts, Architecture and } \\
\text { Design in Prague }\end{array}$ & 0 & 9,626 & 0 & 1,203 & 11,658 & 69.85 \\
\hline Brno University of Technology & 30,654 & 189,359 & 0 & 9,018 & 229,031 & 88.46 \\
\hline University of West Bohemia & 283 & 271,248 & 1,862 & 6,870 & 280,263 & 83.07 \\
\hline Total & 55,953 & $2,533,818$ & 138,714 & 246,924 & $2,977,599$ & 83.69 \\
\hline
\end{tabular}

Source: compiled by the authors.

\subsubsection{Establishing the model}

For further analysis, the data are slightly modified. As dependent variable the amount of points achieved according to the SSRI methodology is selected. In order to express the value of points achieved according to the SSRI methodology, their total amount is divided by the number of employees working at each university. This should reflect the performance of universities in a better way, allowing comparability of universities of a different size.

The independent variables included the following four items: intangible results of research and development, software, valuable rights and other intangible assets. All of these variables are disclosed in the gross book value. The descriptive statistics of the research sample are presented in Table 3. 
Descriptive statistics of the quantitative variables

\begin{tabular}{|c|c|c|c|c|c|}
\hline Statistic & $\begin{array}{c}\text { Intangible results of } \\
\text { research and } \\
\text { development }\end{array}$ & Software & Valuable rights & $\begin{array}{l}\text { Other intangible } \\
\text { assets }\end{array}$ & $\begin{array}{l}\text { SSRI points per } \\
\text { employee }\end{array}$ \\
\hline Count & 206 & 206 & 206 & 206 & 206 \\
\hline Average & $1,007.58$ & $66,192.2$ & $2,521.91$ & $8,669.01$ & 60.4516 \\
\hline Median & 0 & $40,083.7$ & 0 & $4,560.38$ & 52.6341 \\
\hline Standard deviation & $4,012.94$ & $69,819.3$ & $7,474.01$ & $14,336.4$ & 44.1931 \\
\hline Minimum & 0 & 176.12 & 0 & 0 & 0 \\
\hline Maximum & 30,654 & 288,892 & 43,882 & 138,792 & 161.731 \\
\hline Range & 30,654 & 288,716 & 43,882 & 138,792 & 161.731 \\
\hline Lower quartile & 0 & $16,563.8$ & 0 & 1,248 & 20.3659 \\
\hline Upper quartile & 0 & 90,136 & 440.23 & 11,899 & 96.294 \\
\hline Skewness & 5.08168 & 1.63244 & 4.15796 & 6.01543 & 0.436199 \\
\hline Kurtosis & 27.8627 & 1.85714 & 18.1675 & 47.9295 & -0.954642 \\
\hline
\end{tabular}

Source: compiled by the authors.

Assuming a linear relationship exists between the dependent variable and the set of independent variables, the following multiple linear regression model explaining the behaviour of the SSRI per employee according to the independent variables (individual intangible assets) is developed:

SSRI $/$ employee $=\beta_{1} *$ Intangible results of research and development $+\beta_{2} *$ Software $+\beta_{3} *$ Valuable rights $+\beta_{4} *$ Other intangible assets

The multiple regression analysis applies the method of stepwise backward regression to the data gathered. Removing the independent variable "Other intangible assets" from the model in the first step, the final model contains the following parameters (see Table 4).

Table 4

Multiple linear regression

\begin{tabular}{lcccc}
\hline & & Standard & T & \\
\hline Parameter & Estimate $(\beta)$ & Error & Statistic & P-Value \\
\hline Intangible results & 0.001748 & 0.000711 & 2.4599 & 0.0147 \\
\hline Software & 0.000604 & 0.00003 & 18.2637 & 0 \\
\hline Valuable rights & 0.000877 & 0.000385 & 2.2797 & 0.0237 \\
\hline
\end{tabular}

Source: compiled by the authors.

The analysis concluded that all three above mentioned parameters are statistically significant because the P-Value in Table 4 is lower than 0.05 . Therefore, at the $95.0 \%$ confidence level it can be concluded that Intangible results, Software and Valuable rights influence the SSRI per employee. The most important parameter of the regression model is the item software with the P-Value equal to zero. The relationship is shown in Figure 1. 


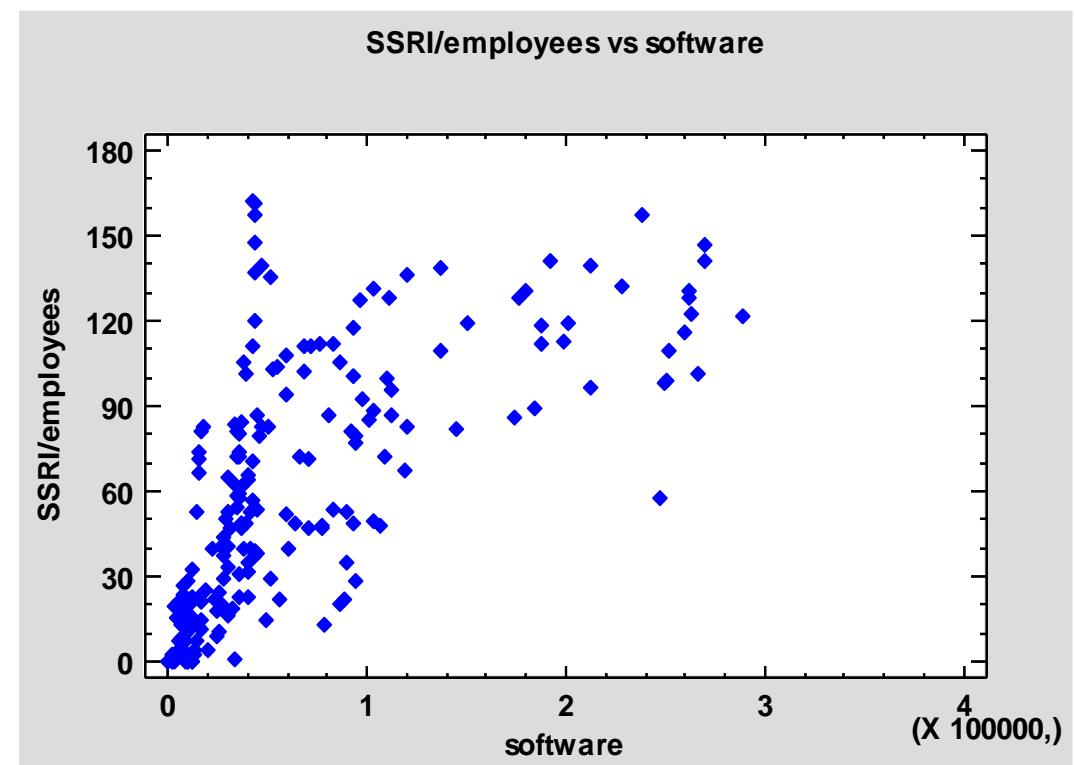

Figure 1. The relationship between SSRI per employee and software Source: compiled by the authors.

Considering the reliability of the proposed regression model, it can be said that it represents a fairly strong association between the independent variables and the dependent variable, since the P-Value of ANOVA is zero. Furthermore, the coefficient of determination (R2) is $72.76 \%$. As the variation of the SSRI per employee is influenced by the three selected items of intangible assets $72.76 \%$, it can be concluded that the SSRI methodology can be replaced by the amount of disclosed intangible assets in the balance sheet.

\section{CONCLUSIONS}

The method used to evaluate the outcomes of research and development activities is based on scoring that is subsequently used for the distribution of financial resources provided by the Government of the Czech Republic. The main drawback of this evaluation is its instability or retrospective change of rules. In addition, the evaluators may apply a subjective approach. As the evaluation includes also the publication activity, the number of publications is rising but their quality is questionable. (Belás, 2014)

On the other hand, the evaluation of scientific outcomes using the amount of intangible assets disclosed in accordance with the requirements of Czech accounting legislation should bring more stability and remove subjective factors from the evaluation process.

It can be concluded that both systems used for the assessment of intangible assets linked to research and development activities have similar weaknesses. The main problem lies in determining the value of individual items. It does not matter if the term value means the measurement of intangible assets or the attribution of points to the outcomes of research and development activities.

In conclusion, it can be noted that the above mentioned approaches use absolute indicators to evaluate intangible assets. In order to compare the performance of public universities in this area relative indicators that would express the intensity and efficiency of intangible assets have to be developed. Such indicators could include, for example, earnings per employee, student or unit of expenses.

To avoid the above mentioned problems, intangible assets should be evaluated by using the IFRS requirements that are valid in most of the developed advanced economies. Changes and their impact have 
to be disclosed in the financial statements of individual subjects. If the value of a certain part of intangible assets was used for the distribution of financial resources provided by the Government of the Czech Republic, research institutions would not sell their intangible assets (copyrights, licences, patents etc.) without disclosing those in their financial statements. Applying this approach would satisfy the basic underlying principle of accounting, namely the true and fair view principle also in the field of intangible assets. This would simultaneously provide an objective allocation base for the creation of the budget of the universities.

\section{ACKNOWLEDGEMENT}

This paper was created in accordance with the institutional support for the conceptual development the Technical University of Liberec, Faculty of Economics. (Project: Excelentní výzkumné týmy - NOVÉ PŘÍSTUPY K VYKAZOVÁNÍ NEHMOTNÝCH AKTIV V PROSTŘEDÍ ČR).

\section{REFERENCES}

Ayerbe, C., Lazaric, N., Callois, M., \& Mitkova, L. (2014). The new challenges of organizing intellectual property in complex industries: a discussion based on the case of Thales. Technovation, 34(4), 232-241.

Belás, J., Bartos, P., Habánik, J., \& Novák, P. (2014). Significant attributes of the business environment in small and meduim-sized enterprises. Economics \& Sociology, 7(3), 22.-39.

Blomqvist, K., Hara, V., Koivuniemi, J., \& Äijö, T. (2004). Towards networked R\&D management: the R\&D approach of Sonera Corporation as an example. R\&D Management, 34(5), 591-603.

Candelin-Palmqvist, H., Sandberg, B., \& Mylly, U. M. (2012). Intellectual property rights in innovation management research: a review. Technovation, 32(9-10), 502-512.

Čada, K. (2009). Oceňování nehmotnébo majetku. Praha: Oecomica.

Cohen, E., \& Davidovitch, N. (2015). Higher education between government policy and free market forces: The case of Israel. Economics \& Sociology, 8(1), 258-274.

Dobiáš, I. (2008). Vádemékum komercializace poznatkư výzkumu a vývoje. Praha: Czech Knowledge Transfer Office.

Hertzfeld, H. R., Link, A. N., \& Vonortas, N. S. (2006). Intellectual property protection mechanisms in research partnerships. Research Policy, 35(6), 825-838.

Holyoak, J., \& P. Torremans. (2013), Intellectual Property Law, Hampshire: Oxford University Press.

Horák, J., \& Malíková, O. (2011). Environmentally related impacts on financial reporting: the case of pollution permits in Czech legislative conditions. WIT Transactions on Ecology and the Environment, 147, 433-442.

IASB. (2014). International accounting standard 38: Intangible assets. London: IASCF.

Hunter, L., Webster, E., \& Wyatt, A. (2012). Accounting for expenditure on intangibles. Abacus, 48(1), 104-145.

Krstić, J., \& Đorđević, M. (2010). Financial Reporting on Intangible Assets: Scope and Limitations. Facta Universitatis, Series: Economics and Organization, 7(3), 335-348.

Lev, B. (2001). Intangibles: management, measurement, and reporting. Washington, D.C.: Brookings Institution Press.

Malíková, O., \& Brabec, Z. (2012). The influence of a different accounting system on informative value of selected financial ratios. Technological and economic development of economy, 18(1), 149-163.

Malíková, O. (2013). Environmental impact identified from company accounts in the Czech Republic. WIT Transactions on Ecology and the Environment, 179, 695-703.

Mingaleva, Z., \& Mirskikh, I. (2013). The Problems of Legal Regulation and Protection of Intellectual Property. Procedia-Social and Behavioral Sciences, 81, 329-333.

Papageorgiadis, N., \& Sharma, A. (2016). Intellectual property rights and innovation: A panel analysis. Economics Letters, 141, 70-72.

Pelegrýn, J. (2011). RIV - nevyčerpatelný zdroj zábavy a poučení. Filosofie dnes, 3(1), 99-104.

Ramírez, Z. Tejada, A., \& Gordillo, S. (2013). REcognition of Intellectual capital importace in the university sector. International Journal of Business and Social Research, 3(4), 27-41.

Regulation No. 504/2002 implementing the Accounting act No. 563/1991. 
Research, Development and Innovation Council. (2016). Research and development and innovation information system of the Czech Republic. Retrieved 20/12/2017 from http://www.isvav.cz/prepareResultForm.doc.

Sedláček. J. (2010). Analysis of the Development of Intangible Assets in the Czech Enterprises and their Impact on Financial Position and Performance. Journal of Economics, 58(4), 375-391.

Svačina, P. (2010). Oceñováni nehmotných aktiv. Praha: Ekopress. 